\title{
LEVEL OF KNOWLEDGE AMONG TURKISH PEOPLE FOR CANCER AND CANCER RISK FACTORS
}

\author{
Murat GULTEKIN, Nejat OZGUL, Emire OLCAYTO, Murat TUNCER
}

Republic of Turkey, Ministry of Health, Department for Cancer Eradication

\begin{abstract}
SUMMARY
Cancer is one of the leading diseases responsible for a majority of deaths in human beings. The incidence of cancer is increasing both in Turkey and in the world, globally. The level of awareness is very important in directing the health policies of cancer prevention, particularly in terms of preventive and screening measures. However, there is not so much well organized trials in Turkey evaluating the level of awareness in the public against cancer disease. In this study, 3,096 people from 26 different provinces across Turkey who were supposed to represent the avarege Turkish population, were evaluated by some questionnaires. With the results of this trial, the authors suggest to find the right policies with scientific evidence to direct the future cancer control activities in Turkey.
\end{abstract}

Key words: awareness, cancer, cancer risk factors, knowledge, Turkey

Journal of Turkish Society of Obstetrics and Gynecology, (J Turk Soc Obstet Gynecol), 2011; Vol: 8 Issue: 1 Pages: $57-61$

\section{ÖZET}

\section{KANSER VE KANSER RISK FAKTÖRLERİ HAKKINDA TÜRK HALKININ BİLGİ DÜZEYINIIN ÖLÇÜLMESI VE ARAŞTIRILMASI}

Kanser tüm dünyada ölüm nedenleri arasında en önde gelen hastalıklardandır. Kanser insidansı da hem ülkemizde hem de tüm dünyada giderek artmaktadır. Kanserle mücadele konusunda özellikle önleme ve tarama çalışmalarının doğru bir şekilde yürütülmesi için toplumdaki farkındalık seviyesi çok önemlidir. Ne yazık ki ülkemizde mevcut farkındalık durumunu ortaya koyan ciddi bir çalışma söz konusu değildir. Bu araştırma da, ülkemizi temsil ettiği düşünülen, 26 ayrı ilden seçilmiş 3096 kişiye kanser hakkındaki mevcut bilgi düzeylerini ölçmeye yönelik bir anket düzenlenmiştir. Araştırma sonuçları ile gelecekteki kanser kontrol faaliyetlerinin daha doğru ve bilimsel temellere dayalı bir şekilde yürütülmesi amaçlanmıştır.

Anahtar kelimeler: bilgi düzeyi, farkındalı, kanser, kanser risk faktörleri, Türkiye

Türk Jinekoloji ve Obstetrik Derneği Dergisi, (J Turk Soc Obstet Gynecol), 2011; Cilt: 8 Sayl: 1 Sayfa: 57-61

Address for Correspondence: Uzm. Dr. Murat Gültekin. TC Sağlık Bakanlığı Kanserle Savaş Dairesi, İlkiz sokak 4/1 Sihhıye, 06000 Ankara Phone: + 90 (312) 5848017

e-mail: mrtgultekin@yahoo.com

Received: 08 June 2010, revised: 08 June 2010, accepted: 21 October 2010, online publication: 15 December 2010 


\section{INTRODUCTION}

Cancer incidence, especially in developing countries, is increasing all over the world ${ }^{(1)}$. In accordance, the incidence of cancer in our country is expected to increase as well(2). In this context, the activities concerning the battle with cancer should be planned in a conscious way and rational policies should be produced. In our country, according to the national cancer control program all of these activities are carried out in four main categories: Prevention, Screening and Early Diagnosis, Treatment and Palliative Care ${ }^{(3)}$. In order to carry out successful policies in this subject matter a certain level of cancer awareness in the society is required. Awareness could be succeded with the training of society within the framework of a developed plan. In this context, the media, civil society organizations and community leaders in cooperation with public education and training in schools is required.

Unfortunately, the studies demonstrating the level of knowledge, the sensitivity and awareness of cancer, which is gradually increasing and affecting the whole community with the consequences is not enough in Turkey ${ }^{(4)}$. Because of this lack of knowledge Ministry of Health, Department of Cancer commissioned a research survey in 26 different cities on 3.096 different individuals. Since this is the first study that aimed to have an idea of level of knowledge and the sensitivity of society it is quite important. Another important point about this study is that this study would allow to develop actionable policies with the data driven from it.

\section{MATERIALS AND METHODS}

This research was carried out by a survey performed in 26 different cities, with 3.096 people by the Republic of Turkey Ministry of Health, Department of Cancer. Polls were done using a private firm with retrieval service which was controlled by the Ministry of Health at every step and the related budet was met entirely by the Ministry of Health. The work for survey was started on August 15, 2009 and was completed on October 1, 2009. The developed questionnaire was used in Ankara as a pilot area, and the interoperability of the questions were seen with the necessary assessments, the final shape of the survey which would be used in the field was determined.
Women and men over 18 years of age constituted the target group of this study. According to the census in 2008 based on the address the target population in these 26 cities is 47,900,845. Accordingly, if the width of the sample is 3.096 individuals in the 26 cities that the study would be performed then the error rate is $5 \%$ and tolerance rate is $1.8 \%$. Sampling distributions of 3.096 individuals representing 26 cities was done according to distirbution of the population considering the NUTS2 classification. Accordingly, the study group $(\mathrm{n}=3096)$ was identified as follows: Adana $(n=128)$, Agri $(n=34)$, Ankara $(n=290)$, Antalya $(n=121)$, Aydin $(n=61)$, Balikesir $(n=67)$, Bursa $(n=148)$, Erzurum $(n=52)$, Gaziantep $(n=120)$, Hatay $(n=92)$, Istanbul $(n=835)$, Izmir ( $n=247)$, Kastamonu $(n=23)$, Kayseri $(n=76)$, Kirikkale ( $\mathrm{n}=17)$, Kocaeli $(\mathrm{n}=95)$, Konya $(\mathrm{n}=124)$, Malatya ( $n=45)$, Manisa ( $n=83)$, Mardin $(n=47)$, Samsun $(n=78)$, Tekirdag $(n=49)$, Trabzon $(n=46)$, Sanliurfa $(\mathrm{n}=100)$, Van $(\mathrm{n}=77)$ and Zonguldak $(\mathrm{n}=41)$.

There are a total of 51 questions in the questionnaire. The first seven questions are compiled from information of participants' demographic characteristics (gender, age, educational status, child status, social security, etc.). The 44 questions taking place in the the second part is about consumed products and general health, and they intend to measure the knowledge of cancer, risks causing cancer, recognition and prevention methods. In the prepared form of questionnaire 3 out of 49 were open-ended questions, 46 of them were closed-ended questions, among the closed ended questions 12 of them were with multiple choices.

The training of all the interviewers and supervisors working in the field was achieved under the supervision of the Ministry of Health, with professional trainers in Ankara. A manual of interviewer was prepared for each interviewer in order to use for questions encountered in the field.

\section{RESULTS}

Among the individuals surveyed $81.9 \%(\mathrm{n}=2535)$ of them were living in urban areas, while $18.1 \%(\mathrm{n}=$ $561)$ of them were living in rural areas. $47.0 \%(n=1456)$ of the participants were female, while $53.0 \%(\mathrm{n}=$ 1640) were male. The distribution of individuals according to the age groups in the survey was as follows: $18-25 n=743$ (24.0\%), 26-35 $n=869$ (28.1\%), 
$36-45 \mathrm{n}=668(21.6 \%), 46-60 \mathrm{n}=587(19.0 \%)$, and 61 years and older $n=229(7.4 \%)$. Educational status of individuals were $173(5.6 \%)$ of them were literate, 1111 of them graduated from primary school (35.9\%), 491 (15.9\%) of them from junior high school, 968 $(31.3 \%)$ of them from high school, $332(10.7 \%)$ of them from, while the remaining 21 people $(0.7 \%)$ had completed post-graduate training programs. More than half of the individuals $(56.2 \%)$ participated in the survey composed the "Housewife-home girl" group and "Craftsmen-Craftsmen" group. $64.9 \%$ of respondents were married $(n=2010), 30.1 \%(n=933)$ of them were single, and the remaining $153(4.9 \%)$ of them were widowed / divorced. While 2011 (65.0\%) individuals had children, 1085 people did not have children $(35.0 \%) .78 .3 \%$ of all participants had health insurance, while the remaining 672 people $(21.7 \%)$ did not have any health insurance.

When the indivuals participating in the survey were questioned about the most appropriate phrase indicating their health status $76.5 \%$ of them described themselves as healthy. The three most common diseases of the individuals in the survey were hypertension $(n=138)$, diabetes $(n=101)$ and heart failure $(n=76)$.

$71.7 \%$ of the individuals surveyed were using acidic foods and beverages $(n=2.220)$. The rates of cigarette and alcohol usage were $45.6 \%(n=1.411)$ and $18.1 \%$ $(\mathrm{n}=559)$, respectively. When the most deadly diseases were asked to the individuals paticipating in the survey $52.1 \%(\mathrm{n}=1.613)$ marked cancer; $25.8 \%$ of them marked AIDS, $8.0 \%$ of them tick bites, $5.7 \%$ of them swine flu, and $5 \%$ marked heart disease. $93.1 \%$ of the individuals regarded cancer as a untreatable fatal disease. Their most important sources of information about cancer were television (68.8\%), neighbor-relatives (40.1\%), newspaper and magazine (30.6\%) and health professionals $(20.6 \%)$. When the individuals were questioned on the state about receiving information about cancer from the health workers $82.9 \%(n=2.568)$ of them stated that they do not receive any information. When the health staff were questioned about the subjects they tell about cancer the answers were that early detection of cancer save lives $(65 \%)$, symptoms of cancer $(49.2 \%)$, cancer therapy $(39.6 \%)$ and cancer prevention methods (33.9\%).

When the participants were asked about the causes of cancer $84.0 \%$ selected smoking, $52.1 \%$ selected alcohol, while unhealthy diet and related choices were selected by $99 \%$ of them. When the symptoms of cancer was questioned fatigue- loss of appetite was stated by $53.2 \%$, while $43.4 \%$ stated swelling, $39.8 \%$ stated unhealed wound, and $32.2 \%$ stated persistent cough and hoarseness. When what you do for protection from cancer was asked; $62.2 \%$ of the participants told that they are taking care of feeding, $44.2 \%$ told they do not smoke, $36.3 \%$ said that they are sheltered from the sun, $32.9 \%$ of them marked choices such as avoiding radiation. When the tests that provide early detection of cancer were asked, $68.9 \%$ of the participants answered as having a check-up during certain periods, $48.2 \%$ getting a chest radiograph, and $20.9 \%$ brain tomography, while having a mammography done was selected by $22 \%$, getting a smear test done by $17.5 \%$, occult blood test in stool by $12.8 \%$. The question on diagnosis of cancer was answered as with blood tests by $50.2 \%$ of the respondents, with biopsy by $32.9 \%$ of them, with tomography by $14 \%$ of them. When their knowledge of cancer was asked $79.9 \%$ have stated as hair loss. To the question of what is chemotherapy $25.3 \%$ of the participants, to what is radiotherapy $50.1 \%$ of them, and to what is mammography $44,6 \%$ of them replied as I do not know. When we asked who do you think should take mammography, only $0.9 \%$ of the respondents gave the right anwer.

Whether the questions in the survey are affected by the different characteristics of individuals (age, gender, education level, marital status, etc.) were investigated with bilateral correlation analysis. As a result, we can say that there is not much difference between the sexes in terms of knowledge about cancer, on the other issues except breast cancer male individuals have more knowledge. In terms of age groups, on cancer, young and middle age groups were better informed than the group $>46$ years old. Individuals with higher levels of education were found to be more knowledgeable about cancer. Moreover, the knowledge levels of employees of the Retirement Fund were higher than those connected to other organizations, including Green Card holders.

Some important questions and answers in this survey were summarized in Table I. 
Table I: A number of striking results according to the survey.

\begin{tabular}{|c|c|}
\hline Question & $\mathbf{N}(\%)$ \\
\hline \multicolumn{2}{|l|}{ Consumed Products } \\
\hline Acidic foods and beverages & $2220(71,7)$ \\
\hline Tobacco & $1411(45,6)$ \\
\hline Alcohol & $559(18,1)$ \\
\hline \multicolumn{2}{|l|}{ Deadly Diseases } \\
\hline Cancer & $1613(52,1)$ \\
\hline AIDS & $799(25,8)$ \\
\hline Tick Bite & $248(8,0)$ \\
\hline Swine Flu & $176(5,7)$ \\
\hline Heart Diseases & $156(5,0)$ \\
\hline \multicolumn{2}{|l|}{ KWhat kind of a Disease is Cancer? } \\
\hline It is a deadly disease & $2883(93,1)$ \\
\hline It is an infectious disease & $110 \quad(3,6)$ \\
\hline It is a desease that can be treated & $37(1,2)$ \\
\hline It is a disease that can be treated & \\
\hline bwith early diagnosis & $16(0,5)$ \\
\hline \multicolumn{2}{|c|}{ From where did you get your information on cancer? } \\
\hline TV & $2131(68,8)$ \\
\hline Neighbours-Relatives & $1241(40,1)$ \\
\hline Newspaper-Magazine & $948(30,6)$ \\
\hline Doctor & $639(20,6)$ \\
\hline \multicolumn{2}{|l|}{ Did you get any information from $t$} \\
\hline Yes & $528(17,1)$ \\
\hline No & $2568(82,9)$ \\
\hline \multicolumn{2}{|l|}{ What do you think causes cancer? } \\
\hline Cigarette & $2601(84,0)$ \\
\hline Alcohol & $1613(52,1)$ \\
\hline Nutrition & $3054(99,0)$ \\
\hline \multicolumn{2}{|l|}{ What are the possible symptoms of cancer? } \\
\hline Fatigue, anorexia, weight loss & $1646(53,2)$ \\
\hline Swelling on any part of the body & $1344(43,4)$ \\
\hline Unhealed Wounds & $1232(39,8)$ \\
\hline Continuous Cough or Hoarseness & $998(32,2)$ \\
\hline Change in appearance of nevus and warts & $983(31,8)$ \\
\hline Unusual Bleeding & $923(29,8)$ \\
\hline \multicolumn{2}{|l|}{ What are you doing for cancer prevention? } \\
\hline I pay attention to my nutrition & $1926(62,2)$ \\
\hline I do not smoke & $1368(44,2)$ \\
\hline \multicolumn{2}{|l|}{ Methods for Early Diagnosis of Cancer } \\
\hline Check-Up at Certain Periods & $2134(68,9)$ \\
\hline Getting chest films & $1492(48,2)$ \\
\hline Getting breast films & $680(22,0)$ \\
\hline Getting brain tomography & $648(20,9)$ \\
\hline Self examination of breats & $640(20,7)$ \\
\hline Sampling of the cervix (smear test) & $541(17,5)$ \\
\hline Searching for blood cells in stools & $397(12,8)$ \\
\hline I do not know & $309(10,0)$ \\
\hline \multicolumn{2}{|l|}{ What is chemotherapy in your opinion? } \\
\hline I do not know & $783(25,3)$ \\
\hline \multicolumn{2}{|l|}{ What is radiotheraphy in your opinion? } \\
\hline I do not know & $1550(50,1)$ \\
\hline \multicolumn{2}{|l|}{ What is mammography in your opinion? } \\
\hline I do not know & $1382(44,6)$ \\
\hline \multicolumn{2}{|l|}{ Who do you think should have a mamogram? } \\
\hline Women & $1218(39,3)$ \\
\hline$>35$ years-old women & $466(15,1)$ \\
\hline Everyone & $350(11,3)$ \\
\hline$>50$ years-old women & $57(1,8)$ \\
\hline I do not know & $1005(32,5)$ \\
\hline
\end{tabular}

\section{DISCUSSION}

In general terms, this research is a survey model. Screening models are the research models that aim to precisely describe a situation in the past or a situation that currently exists. The main purposes of these models are to produce healthy information for the decision maker in order to develop a strategy.

A limited number of studies were performed in order to investigate the the level of awareness of people about cancer. Existing studies were usually performed on a limited number of people from a particular region. In this context, these studies cannot possibly represent the whole country. This study is the first that has a sufficient number of participants and was performed in 26 different cities of our country and the results reflectthe level of whole country. In accordance with the facts determined according to the results of this study, public education and selection of the right policies in this education would be possible. According to a number of striking findings of this study summarized in Table I;

a. Goods consumed in our country: The rate of smoking in our country is still at a very high level (45,6\%). Moreover, consumption of acidic food is over $70 \%$, alcohol use is $18 \%$. According to these findings, in the fight against cancer our most important strategy should be the fight against tobacco. Even though an increased level of awareness was ensured among our people with the tobacco law that came up in the recent years, our people are not fully convinced that smoking causes cancer. While only $89 \%$ of the participants stated smoking as a cause of cancer, $99 \%$ of the respondents marked nutrition as a possible cause of cancer. In addition, there is a lack of behavior about tobacco among our people. $89 \%$ of the people indicates smoking as a cause of a cancer, but in response to the question on what they do for the protection from cancer only $44 \%$ of them answered that they do not smoke. However, interestingly, $66 \%$ of them underlined that they are careful about nutrition.

\section{b. Importance of nutrition in our country: Sufficient} awareness about nutrition was developed on our people. In this context, there is an important contribution from the nutrition experts that are on the television shows every day in the recent 
years. $99 \%$ of the participants emphasized nutrition as a possible cause of cancer and adapted this as the most important preventive measure against cancer $(66 \%)$

c. Perception of Cancer: Unfortunately, the perspective of our citizens on cancer is quite negative. The terminology of cancer is settled as a serious stigma on our people. While $52 \%$ of respondents marked cancer as the most deadly disease, 93\% of them defined cancer as a fatal disease.

d. Information related to cancer: The vast majority of our people obtain the current knowledge about cancer through the television. In this context, television should be the core for public education and activities that would create awareness. Other means of communication such as newspaper, magazines, radio do not have the same impact.

e. Training of the Health Staff: Unfortunately, many health professionals do not provide enough information about cancer, its symptoms and screening tests to the patients admitted. Only $17 \%$ of the participants were informed about cancer by the health workers. In this context, health care workers should be fully informed and the patients admitted should be informed at least about cancer screening.

f. Current Information Status on Cancer: This study revealed that, unfortunately, our people do not have sufficient and accurate information about cancer. Among the participants of the survey 25\% of them stated that they did not have any information about chemotherapy, 50\% of them about radiotherapy and $44 \%$ of them about mammography, and only $1.8 \%$ of the participants knew about the breast cancer screening according to national standards.

\section{RESULTS}

In the light of all these data, one can say that the level of awareness and knowledge about cancer among our people is at a very low level. In particular, nutrition seems to gain much importance in the eyes of our people. Further training sessions should be carried out about the harmful effects of smoking and other carcinogens. Existing perception of cancer should be replaced, screening programs for the early detection and that anyone could be cured with early detection should be taught. There is an undeniable role of television in public education and global policy makers should work with professional PR firms.

\section{REFERENCES}

1. Peter Boyle, Bernard Levin. World Cancer Report 2008. World Health Organization, International Agency for Research on Cancer, 2008

2. www.ketem.org/kanseristatistikleri

3. Ulusal Kanser Kontrol Programı. A. Murat Tuncer. TC Sağlık Bakanlığı Yayınları, 2009, Ankara

4. Samur M. Kanser Tanısı Almış Hastaların Bilgilendirilme Durumu; Hekim ve Hekim Adaylarının Yaklaşımları Hakkında Ankara Üniversitesi Tıp Fakültesi İbni Sina Hastanesi'nde Yapılan Sınırlı Bir Araştırmanın Sonuçları, Ankara Üniversitesi Tıp Fakültesi Mecmuası, 2000; 53: 161-6. 